\title{
KOMPARASI PENDAPATAN USAHATANI BAWANG MERAH BERDASARKAN SUMBER PEMBIAYAAN DI KABUPATEN NGANJUK
}

\author{
Aris Farianto ${ }^{1}$, Tuti Karyani ${ }^{2}$, dan Lucyana Trimo ${ }^{3}$ \\ 1)Program Magister Ilmu Pertanian Fakultas Pertanian Padjadjaran \\ 2,3) Fakultas Pertanian Universitas Padjadjaran \\ Jl. Raya Bandung Sumedang KM 21, Jatinangor, Jawa Barat, Indonesia \\ e-mail: 1)aris_farianto@yahoo.co.id
}

(Diterima 10 November 2020/Revisi 3 Desember 2020/Disetujui 7 Januari 2021)

\begin{abstract}
Shallots in Indonesian society as a complement to spices in cooking, are also needed as raw material for the fried onion industry and have many benefits of high economic value. Shallot consumption has risen year after year, resulting in a rise in shallot commodity development. The scale of onion farming variety from small to large scale; it demands a significant amount of capital gets started. One of the most essential aspects of initiatives to promote a shallot commodity, which is intended to boost farmers' income, is the availability of funding. The purpose of this study was to determine the income between shallot farmers who access credit to formal and informal financial institutions. The research was conducted in Nganjuk Regency because it is one of the centres of shallots in East Java Province. The analysis in this research is analyzing farm income and examining the differences between farms that have access to formal and informal. The results showed that the income of shallot farming in Nganjuk Regency was very profitable and there was a difference between the income of shallot farming who accessed formal and informal financial institutions.
\end{abstract}

Keywords:farming, income, shallots

\begin{abstract}
ABSTRAK
Komoditi bawang merah bagi masyarakat tidak dapat dipisahkan dari konsumsi sehari-hari, masyarakat sudah sangat tergantung dengan komoditi ini, sehingga walaupun harganya naik masyarakat akan tetap mencari untuk mendapatkannya. Konsumsi bawang merah yang mengalami peningkatan setiap tahunnya mengakibatkan meningkatnya juga pengembangan akan komoditi bawang merah. Skala usahatani bawang merah yang beragam dari skala kecil maupun skala besar, untuk melakukan usahatani diperlukan modal yang cukup tinggi. Sumber pembiayaan merupakan salah satu komponen penting dalam upaya pengembangan komoditi bawang merah, diharapkan mampu meningkatkan pendapatan petani. Penelitian mempunyai tujuan mengetahui perbedaan pendapatan yang mengakses modal ke lembaga keuangan formal dan informal. Penelitian dilakukan di Kabupaten Nganjuk. Penentuan sampel menggunakan purposive sampling. Sampel yang digunakan penelitian sebanyak 100 petani bawang merah yang memperoleh kredit dari lembaga keuangan formal dan informal. Metode penelitian menggunakan pendekatan analisis kuantitatif. Analisis data menggunakan analisis matematik untuk mengetahui pendapatan petani bawang merah yang memperoleh kredit dari lembaga keuangan formal dan informal. Analisis statistik digunakan untuk mengetahui perbedaan kedua usahatani yang memperoleh kredit dari lembaga keuangan formal dan informal. Hasil penelitian menunjukkan rata-rata pendapatan petani bawang merah yang mengakses lembaga keuangan formal sebesar Rp 73.523.537,34 per hektar/MT dan pendapatan petani bawang merah yang mengakses lembaga keuangan informal sebesar Rp 43.322.487,38 per hektar/MT. Berdasarkan analisis Komparasi pendapatan yang diperoleh usahatani bawang merah yang mengakses kredit ke lembaga keuangan formal dan informal terdapat perbedaan nyata antara usahatani bawang merah yang mengakses kredit ke lembaga keuangan formal dan informal.
\end{abstract}

Kata kunci: bawang merah, pendapatan, usahatani 


\section{PENDAHULUAN}

Perkembangan komoditi bawang merah dilihat dari segi ekspor impor nasional. Volume ekspor dan impor selama tahun 2014 sampai 2018 mengalami fluktuatif, namun cenderung meningkat. Pada tahun 2015 merupakan tahun dengan volume ekspor tertinggi sebanyak 8.418.274 ton, dan pada tahun 2016 merupakan terendah sebanyak 735.688 ton. Sementara ekspor dalam bentuk bibit tidak dilakukan. Sedangkan jumlah impor bawang dalam bentuk konsumsi dan bibit tertinggi pada tahun 2014 dengan jumlah 74.903 ton, kemudian pada tahun 2015 terjadi penurunan impor bawang merah menjadi 17.429 ton (Kemendag, 2020).

Berdasarkan Permentan nomor 60 tahun 2012 tentang kebijakan batasan impor bawang merah, untuk tujuan melindungi petani didalam negeri dengan mempertimbangkan jadwal tanam serta kemampuan produksi bawang merah nasional sebelum dilakukan impor, maka pada priode 2014 sampai 2018 indonesia mengalami penurunan impor bawang merah sebesar 93,01 persen.

Dilihat dari prospek konsumsi masyarakat, komoditi bawang merah bagi masyarakat sangat dibutuhkan untuk konsumsi seharihari, masyarakat sudah sangat tergantung dengan komoditi ini, sehingga walaupun harganya naik pun masyarakat akan tetap mencari untuk mendapatkannya. Konsumsi bawang merah setiap tahunnya mengalami peningkatan, pada tahun 2016 mencapai 3,4 kg per kapita/tahun (BPS Provinsi Jawa Timur, 2016).

Kabupaten Nganjuk salah satu daerah yang sangat berpontesi disektor pertanian, dengan luas wilayah pertanian 43.026 hektar dan mayoritas penduduk bekerja sebagai petani. Sektor pertanian menjadi sektor unggulan bagi Kabupaten Nganjuk dapat dilihat dari distribusi persentase Produk Domestik Regional Bruto Atas Dasar Harga Berlaku terhadap total PDRB selalu diatas 30\% (BPS Kabupaten Nganjuk dalam angka, 2018). Kabupaten Nganjuk memiliki 20 kecamatan dimana 14 kecamatan merupakan daerah penghasil bawang merah. Kecamatan dengan kontribusi bawang merah terbesar terdapat di kecamatan, Rejoso, Bagor, Gondang, Sukomoro, dan Wilangan ( Dinas Penanam Modal dan Pelayanan Terpadu Kabupaten Nganjuk tahun 2018)

Melihat potensi bawang merah yang strategis dan komoditas unggulan wilayah Nganjuk, maka tidaklah mengherankan apabila Kabupaten Nganjuk oleh Kementerian Pertanian ditunjuk sebagai sentra produksi bawang merah dan penyangga produksi nasional. Tapi pada kenyataannya dilapangan tidak sesuai diharapkan. Pada beberapa tahun terakhir ini produksi bawang merah di Kabupaten Nganjuk menunjukkan hasil produktifitas yang menurun. Hal ini dapat dilihat dari jumlah produksi tahun 2017 mencapai 126.571 ton, dibandingkan pada tahun 2014 dimana jumlah produksi bawang merah mampu mencapai 140.229 ton. (Kabupaten Nganjuk dalam angka, 2018).

Penurunan produksi di Kabupaten Nganjuk disebabkan karena usahatani bawang merah mengalami masalah yang kompleks, beberapa masalah yang saat ini diduga menjadi kendala dalam usahatani bawang merah, diantaranya 1) Pendapatan petani masih tergolong rendah, 2) Penurunan sumber daya pertanian, 3) Keterbatasan atas modal usahatani, 4) Rantai pemasaran belum optimal, 5) Penerapan teknologi pada umumnya masih lemah, dan 6) peningkatan intensitas kejadian iklim ekstrim (Dinas Pertanian Nganjuk, 2018).

Berdasarkan hasil penelitian Basuki (2014) mengemukakan bahwa petani bawang merah, masih mempunyai permasalahan mengenai keterbatasan modal ketika membeli inputinput usahatani, seperti pupuk dan pestisida.

Berdasarkan laporan Dinas Pertanian Nganjuk (2018) mengemukakan akses petani kepada modal, informasi yang didapatkan dan luas lahan sangat penting untuk meningkatkan kinerja usahatani. Petani bawang merah mempunyai kendala dalam mengakses modal ke lembaga sumber pembiayaan. Keterbatasan ini disebabkan, keberadaan lembaga pembiayaan disetiap desa masih 
kurang, prosedur dan syarat-syarat yang ditentukan lembaga dinilai masih sulit oleh petani dan suku bunga yang tinggi.

Peningkatan akses masyarakat terhadap modal telah diupayakan Dinas Pertanian Kabupaten Nganjuk melalui kegiatan Bantuan Langsung Masyarakat (BLM) dan lembaga lainnya turut andil dalam memberikan modal, dengan berbagai kegiatan, seperti peningkatan koperasi dan usaha kecil menengah, lembaga keuangan mikro dan BRI unit desa. Kegiatan tersebut memberikan dampak yang baik, namun masih perlu ditingkatkan lagi agar masyarakat dapat menjangkau secara luas. Dinas Pertanian Nganjuk, 2018).

Lemahnya akses petani terhadap modal dapat dijadikan dugaan bahwa usahatani komoditas bawang merah membutuh biaya yang cukup besar selama proses budidayanya. Kelemahan modal merupakan kendala yang sering sekali dihadapi oleh petani, karena usahatani bawang merah membutuhkan banyak modal, baik untuk kebutuhan pembelian input dan tenaga kerja. Kebutuhan modal yang diperlukan petani sebesar 15 juta per 0,14 hektar atau Rp.105.000.000 per hektar. (Bank Indonesia Wilayah Jawa Timur). Kecukupan modal melalui akses ke lembaga pembiayaan dapat berdampak kepada optimalnya dalam skala usaha dan adopsi teknologi yang akhirnya dapat meningkatkan pendapatan petani bawang merah.

Akses kredit ke lembaga pembiayaan merupakan hak semua petani dan masyarkat yang menjadi penting dalam meningkatkan modal kegiatan usahataninya. Kondisi sekarang, banyak lembaga keuangan formal dan informal yang menyediakan modal kepada petani, kesulitan dalam modal. Lembaga penyedia modal seperti LKM, pemerintah melalui kelompok tani, kios pertanian (Wulandari, et al, 2017). Namun, dalam proses mendapatkan sumber modal tersebut tidak semata-mata memberikan modal. Tetapi petani akan mengakses ke lembaga keuangan harus memenuhi prosedur yang telah ditentukan lembaga keuangan.
Dampak mengakses kredit berpengaruh terhadap kegiatan usahatani. Hasil penelitian Wati, dkk (2014) menunjukan bahwa Ratarata hasil produksi padi yang menerima kredit sebanyak 4,77 ton dan petani tidak menerima kredit sebesar 5,52 ton. Hasil panen tersebut tidak dapat disimpulkan bahwa petani yang tidak menerima kredit lebih produktif. Petani penerima kredit pada musim panen banyak mengalami kerugian, disebabkan banyak serangan hama burung.

Berdasarkan uraian tersebut, maka tujuan penelitian adalah apakah terdapat perbedaan pendapatan usahatani bawang merah yang mengakses kredit ke lembaga keuangan formal dan informal.

\section{METODE}

\section{PENGUMPULAN DATA DAN ANALISIS}

Lokasi penelitian dilaksanakan di Kabupaten Nganjuk dengan pertimbangan merupakan daerah penyumbang produksi bawang merah terbesar di Jawa Timur. Penentuan daerah penelitian dilakukan dengan cara Purposive untuk memilih daerah mana yang akan dijadikan lokasi penelitian. Kabupaten Nganjuk memiliki 20 Kecamatan. Kecamatan yang dipilih sebagai lokasi penelitian yaitu Kecamatan Rejoso, Kecamatan Bagor dan Kecamatan Gondang, karena ketiga kecamatan tersebut merupakan menghasilkan produksi bawang merah terbesar diantara kecamatan lainnya. (Dinas Pertanian Kabupaten Nganjuk, 2018). Penelitian dilaksanakan pada bulan Juli sampai bulan September tahun 2020.

Pengambilan sampel dilakukan dengan cara simple random sampling. Berdasarkan pemilihan petani yang mengakses dilakukan dengan memilih (menjaring) ketika melakukan wawancara. Data hasil Simluhtan jumlah populasi sebanyak 35.625 petani, sehingga jumlah responden dalam penelitian ini sebanyak 100 petani bawang merah, untuk mempermudah keperluan analisis dan pendistribusian jumlah responden secara merata di ketiga kecamatan tersebut. 
Responden yang terpilih selanjutnya dikelompokkan berdasarkan jumlah kelompok tani yang terdapat pada setiap kecamatan. Berdasarkan Simluhtan jumlah kelompok tani di Kecamatan Rejoso sebanyak 114 kelompok tani, Kecamatan Bagor sebanyak 97 kelompok tani dan Kecamatan Gondang sebanyak 80 kelompok tani. Berikut alur proses penentuan lokasi dan sampel di tampilkan di Gambar 1.

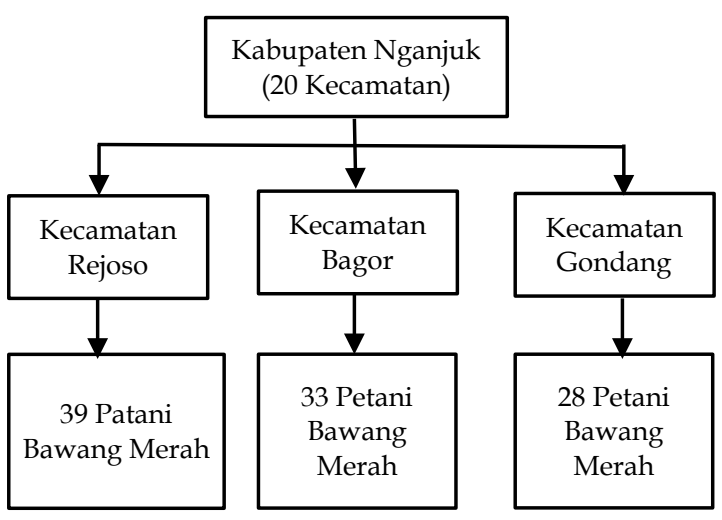

Gambar 1. Alur Penentuan Lokasi dan Sampel.

Teknik pengumpulan data primer, melakukan wawancara langsung kepada petani yang menjadi responden dengan panduan kuesioner yang telah disusun dan melakukan pengataman langsung dilokasi penelitian Daftar pertanyaan terdiri dari karakteristik responden dan usahataninya, data produksi, biaya input usahatani, penerimaan usahatani bawang merah, dan sumber-sumber biaya yang digunakan, serta berbagai kendala dan permasalahan dihadapi petani. Data pendukung penelitian berupa data sekunder yang diperoleh dari lembaga-lembaga yang mempengaruhi langsung dengan pengembangan usahatani bawang merah, yakni; Balai Penyuluhan Pertanian (BPP) Kabupaten Nganjuk, Bank umum dan lembaga keuangan informal di lokasi penelitian, Badan Pusat Statistik Kabupaten Nganjuk, dan Kantor Dinas Pertanian Kabupaten Nganjuk.

\section{METODE ANALISIS}

Pendapatan usahatani ditentukan dari hasil produksi yang diperoleh kemudian dikurangi biaya penggunaan input atau biaya total, maka variabel tersebut dimasukkan ke dalam persamaan hasil yang merupakan tahap kedua dari model ini adalah sebagai berikut:

$$
\Pi=\mathrm{TR}-\mathrm{TC}
$$

Keterangan:

п : Pendapatan ( $\mathrm{Rp} / \mathrm{Ha})$

TR: Total revenue atau total penerimaan ( $\mathrm{Rp} / \mathrm{Ha})$

TC : Total biaya $(\mathrm{Rp} / \mathrm{Ha})$

Dilakukannya uji beda untuk mengetahui perbedaan antara pendapatan usahatani bawang merah yang mengakses ke lambaga keuangan formal dan informal. Uji beda dilakukan untuk kedua pendapatan. Uji beda dilakukan menggunakan Uji-T untuk dua sampel berpasangan karena sampel yang digunakan sama antara kedua usahatani. Adapun prosedur Uji-T untuk dua sampel berpasangan adalah sebagai berikut (Sugiyono, 2010):

$$
t=\frac{X 1-X 2}{\sqrt{\frac{n 1-1) s 1^{2}+(n 2-1) s 2^{2}}{n 1+n 2-2} X\left(\frac{1}{n 1}+\frac{1}{n 2}\right)}}
$$

Keterangan :

X1 : rata- rata pendapatan formal

$\mathrm{X} 2$ : rata-rata pendapatan informal

$\mathrm{Ni}$ : jumlah sampel kelompok formal

N2 : jumlah sampel kelompok informal

$\mathrm{S}^{2}$ : deviasi standar kelompok formal

$\mathrm{S}^{2}$ : deviasi standar kelompok informal

\section{Hipotesis penelitian:}

$$
\mathrm{H} 0: \mu 1 \neq \mu 2
$$

Diduga pendapatan usahatani bawang mengakses ke lembaga keuangan formal dengan usahatani bawang yang mengakses keuangan informal.

\section{Pengambilan keputusan}

Jika

$\mathrm{t}_{\text {hitung }}<\mathrm{t}_{\text {tabel }} \mathrm{a}=5 \% \mathrm{db}=(\mathrm{n} 1+\mathrm{n} 2)-2$ Terima Ho $t_{\text {hitung }}>t_{\text {tabel }} a=5 \% d b=(n 1+n 2)-2$ tolak Ho 


\section{HASIL DAN PEMBAHASAN}

\section{KARAKTERISTIK RESPONDEN}

Responden penelitian merupakan petani bawang merah yang mengakses modal usahatani dari lembaga keuangan formal dan informal di Kabupaten Nganjuk. Karakteristik responden dilihat dari umur, pendidikan, pengalaman usahatani, jumlah tanggungan keluarga, luas lahan dan jumlah kredit. Adapun karakteristik petani sebagai berikut:

\section{Umur}

Umur merupakan indikator berhubungan dalam kemampuan kerja untuk melakukan usahatani. Umur petani merupakan aspek penting, dapat mempengaruhi petani dalam mengambil suatu tindakan dan keputusan yang berhubungan dengan usahataninya yang sedang berjalan. Umur seorang petani yang masih produktif tentu memilki kondisi fisik yang sehat untuk menjalankan aktivitas dalam bertani/berusahatani. Petani berumur tua lebih cenderung bersikap konservatif dan kurang tanggap mengenai perubahan inovasi teknologi (Soekartawi, 2006). Data yang mengambarkan keadaan umur petani bawang merah dilokasi penelitian dituangan pada Tabel 1.

Tabel 1. Sebaran Umur Petani Bawang Merah Kabupaten Nganjuk

Petani Bawang Merah Petani Bawang Merah

\begin{tabular}{ccccc}
\multirow{2}{*}{$\begin{array}{c}\text { Umur } \\
\text { (Tahun) }\end{array}$} & \multicolumn{2}{c}{$\begin{array}{c}\text { Mengakses Lembaga } \\
\text { Keuangan Formal }\end{array}$} & $\begin{array}{c}\text { Mengakses Lembaga } \\
\text { Keuangan Informal }\end{array}$ \\
\cline { 2 - 5 } & $\begin{array}{c}\text { Jumlah } \\
\text { (Orang) }\end{array}$ & $\begin{array}{c}\text { Persentase } \\
(\%)\end{array}$ & $\begin{array}{c}\text { Jumlah } \\
\text { (Orang) }\end{array}$ & $\begin{array}{c}\text { Persentase } \\
(\%)\end{array}$ \\
\hline $30-40$ & 4 & 20,00 & 14 & 17,50 \\
$40-50$ & 12 & 60,00 & 38 & 47,50 \\
$50-59$ & 4 & 20,00 & 24 & 30,00 \\
$>60$ & 0 & 0 & 4 & 5,00 \\
Jumlah & 20 & 100,00 & 80 & 100,00 \\
\hline
\end{tabular}

Berdasarkan Tabel 1, umur petani bervariasi antara umur 30 sampai umur 60 tahun, namun rata-rata usia petani antara 40 sampai 50 tahun, hal ini menunjukkan bahwa petani bawang merah Kabupaten Nganjuk rata-rata masih pada usia produktif. Hal ini memperlihatkan bahwa petani bawang merah di lokasi penelitian masih tergolong dalam usia pro- duktif. Menurut Rusli (2012) usia produktif berkisaran antara 15 sampai 64 tahun.

\section{Tingkat Pendidikan}

Pendidikan merupakan salah satu faktor pembangunan dan kualitas SDM. Penelitian ini melihat pendidikan formal yang telah diselesaikan oleh petani. Pendidikan yang sudah ditamatkan oleh petani responden meliputi SD, SMP, SMA dan Perguruan tinggi. Berikut sebaran tingkat pendidikan petani petani bawang merah di Kabupaten Nganjuk.

\begin{tabular}{|c|c|c|c|c|}
\hline & $\begin{array}{l}\text { Jawang } \\
\text { Jganjuk }\end{array}$ & Merah & di & oupaten \\
\hline \multirow[t]{2}{*}{$\begin{array}{l}\text { Tingkat } \\
\text { Pendidikan }\end{array}$} & \multicolumn{2}{|c|}{$\begin{array}{c}\text { Petani Bawang } \\
\text { Merah Mengakses } \\
\text { Lembaga Keuangan } \\
\text { Formal } \\
\end{array}$} & \multicolumn{2}{|c|}{$\begin{array}{c}\text { Petani Bawang } \\
\text { Merah Mengakses } \\
\text { Lembaga Keuangan } \\
\text { Informal } \\
\end{array}$} \\
\hline & $\begin{array}{l}\text { Jumlah } \\
\text { (Orang) }\end{array}$ & $\%$ & $\begin{array}{l}\text { Jumlah } \\
\text { (Orang) }\end{array}$ & $\%$ \\
\hline SD & 8 & 40,00 & 36 & 45,00 \\
\hline SMP & 9 & 45,00 & 30 & 37,50 \\
\hline SMA & 1 & 5,00 & 14 & 17,50 \\
\hline Sarjana & 2 & 10.00 & 0 & 0 \\
\hline Jumlah & 20 & 100,00 & 80 & 100,00 \\
\hline
\end{tabular}

Persentase tingkat pendidikan yang berhasil ditamatkan oleh petani bawang merah di Kabupaten Nganjuk yaitu pada tingkat Sekolah Dasar (SD). Hal ini menggambarkan bahwa pendidikan petani lebih didominasi oleh petani dengan tingkat pendidikan berada tergolong rendah.

Menurut Mosher (1987), bahwa pendidikan merupakan salah satu faktor pelancar kegiatan usahatani, artinya semakin tinggi pendidikan yang ditempuh petani maka pengetahuan dan wawasan petani juga akan semakin bertambah. Rendahnya tingkat pendidikan formal yang berhasil ditamatkan petani bawang merah di Kabupaten Nganjuk menyebabkan kemampuan petani dalam mengelola usahatani menjadi kurang maksimal. Rendahnya pendidikan juga menyebabkan rendahnya wawasan dan kreatifitas yang dapat menyebabkan menurunkan produktivitas petani dalam menghasilkan produk pertanian dan tanaman pangan. Selain itu, kurangnya pengetahuan petani menyebabkan 
petani kurang berpikir rasional dalam menghadapi resiko usahatani.

\section{Pengalaman Usahatani}

Pengalaman usahatani bawang merah yang sudah dijalankan petani dapat memberikan kemampuan bertani dalam pengetahuan teknik budidaya dan kemampuan adopsi pada kegiatan usahatani yang sedang dijalankan. Semakin banyak pengalaman bertani maka semakin tinggi kemampuan dan keterampilan petani dalam mengelola usahatani. Berikut data sebaran pengalaman usahatani bawang merah Kabupaten Nganjuk.

Tabel 3. Pengalaman Petani dalam Berusahatani Bawang Merah Kabupaten Nganjuk

\begin{tabular}{|c|c|c|c|c|}
\hline \multirow[t]{2}{*}{$\begin{array}{c}\text { Pengalaman } \\
\text { Bertani } \\
\text { (Tahun) }\end{array}$} & \multicolumn{2}{|c|}{$\begin{array}{c}\text { Petani Bawang } \\
\text { Merah } \\
\text { Mengakses } \\
\text { Lembaga } \\
\text { Keuangan } \\
\text { Formal } \\
\end{array}$} & \multicolumn{2}{|c|}{$\begin{array}{c}\text { Petani Bawang } \\
\text { Merah } \\
\text { Mengakses } \\
\text { Lembaga } \\
\text { Keuangan } \\
\text { Informal } \\
\end{array}$} \\
\hline & $\begin{array}{l}\text { Jumlah } \\
\text { (Orang) }\end{array}$ & $\%$ & $\begin{array}{l}\text { Jumlah } \\
\text { (Orang) }\end{array}$ & $\%$ \\
\hline $1-10$ & 6 & 30,00 & 31 & 38,75 \\
\hline $11-20$ & 9 & 45,00 & 33 & 41,25 \\
\hline $21-30$ & 4 & 20,00 & 13 & 16,25 \\
\hline $31-40$ & 1 & 5,00 & 3 & 3,75 \\
\hline Jumlah & 20 & 100,00 & 80 & 100,00 \\
\hline
\end{tabular}

Berdasarkan lama pengalaman petani pada Tabel 3, menunjukkan bahwa sebagian besar petani memiliki pengalaman berusahatani bawang merah sudah cukup lama. Pengalaman petani dalam bertani bawang merah di Kabupaten Nganjuk rata-rata 11 sampai 20 tahun.

Pengalaman merupakan salah satu indikator penentu keberhasilan dalam menjalankan usahatani, biasanya pengalaman berusahatani sebelumnya dapat menambah pelajaran untuk kegiatan usahatani selanjutnya. Hal tersebut merupakan berkaitan dengan risiko. Menurut Yunita (2011) pengalaman yang dimiliki petani memiliki kemampuan menjalankan lebih baik dalam berusahatani, hal ini dikarenakan pengalaman memberikan pelajaran kepada petani, untuk menghadapi masalah yang terjadi. Berdasarkan pengalamannya tersebut, menurut Suratiyah (2006) petani dapat mengetahui cara mengatasi ber- bagai masalah yang seringkali dihadapi dalam kegaiatan usahanya.

\section{Jumlah Tanggungan Kelurga Petani}

Semakin banyak jumlah tanggungan dalam keluarga maka semakin besar juga beban yang harus dipenuhi oleh petani. Walaupun demikian, dengan semakin banyak jumlah tanggungan keluarga akan berguna untuk membantu dalam kegiatan berusahatani.

Ukuran tanggungan keluarga yang diperhitungkan dari jumlah anggota kelurga yang tinggal satu rumah tangga petani. Hasil penelitian menunjukan bahwa dalam satu tempat tinggal terdiri dari istri, anak menantu, cucu dan kedua orang tua petani. Ukuran petani bervariasi yang berkisaran 1-7 orang, rata-rata sebanyak 4 tanggungan. Berikut data sebaran tanggungan petani bawang merah Kabupaten Nganjuk disajikan pada Tabel berikut.

Tabel 4. Sebaran Jumlah Tanggungan Keluarga Petani Bawang Merah Kabupaten Nganjuk

\begin{tabular}{ccccc}
\hline Jumlah & $\begin{array}{c}\text { Petani Bawang } \\
\text { Merah } \\
\text { Mengakses } \\
\text { Temggungan } \\
\text { Keluarga }\end{array}$ & $\begin{array}{c}\text { Kembaga } \\
\text { Keuangan } \\
\text { Formal }\end{array}$ & $\begin{array}{c}\text { Petani Bawang } \\
\text { Merah } \\
\text { Mengakses } \\
\text { Lembaga } \\
\text { Keuangan } \\
\text { Informal }\end{array}$ \\
\cline { 2 - 5 } & Jumlah & Jumlah & $\%$ \\
(Orang) & $\%$ & (Orang) & $\%$ \\
\hline 3 & 8 & 40,00 & 14 & 17,50 \\
5 & 7 & 35,00 & 31 & 38,75 \\
6 & 2 & 10,00 & 19 & 23,75 \\
7 & 2 & 10,00 & 12 & 15,00 \\
Jumlah & 1 & 5,00 & 4 & 5,00 \\
& 20 & 100,00 & 80 & 100,00 \\
\hline
\end{tabular}

\section{Luas Lahan}

Petani dapat melakukan aktifitas berusahatani di lahan pertanian. Petani bawang merah di lokasi penelitian mempunyai lahan sendiri dan ada juga yang menyewa untuk kegiatan usahatani. Pada Tabel 5 menjelaskan luas lahan yang di miliki petani bawang merah di Kabupaten Nganjuk.

Berdasarkan Tabel 5, luas lahan garapan usahatani bawang merah berada kisaran 0,112 sampai 1 hektar, dengan rata-rata luas lahan 0,1 sampai 0,3 hektar, hal ini menunjukan penguasahan lahan untuk usahatani bawang 
merah di Kabupaten Nganjuk masih kurang, disebabkan oleh alih fungsi lahan.

Tabel 5. Sebaran Luas Lahan Petani Bawang Merah Kabupaten Nganjuk

\begin{tabular}{|c|c|c|c|c|}
\hline \multirow[t]{2}{*}{$\begin{array}{c}\text { Luas } \\
\text { Lahan } \\
\text { (Hektar) }\end{array}$} & \multicolumn{2}{|c|}{$\begin{array}{c}\text { Petani Bawang } \\
\text { Merah } \\
\text { Mengakses } \\
\text { Lembaga } \\
\text { Keuangan } \\
\text { Formal }\end{array}$} & \multicolumn{2}{|c|}{$\begin{array}{c}\text { Petani Bawang } \\
\text { Merah } \\
\text { Mengakses } \\
\text { Lembaga } \\
\text { Keuangan } \\
\text { Informal }\end{array}$} \\
\hline & $\begin{array}{l}\text { Jumlah } \\
\text { (Orang) }\end{array}$ & $\%$ & $\begin{array}{l}\text { Jumlah } \\
\text { (Orang) }\end{array}$ & $\%$ \\
\hline $0,1-0,3$ & 3 & 15,00 & 40 & 50,00 \\
\hline $0,3-0,5$ & 7 & 35,00 & 35 & 43,75 \\
\hline $0,5-0,7$ & 6 & 30,00 & 5 & 6,25 \\
\hline $0,7-0,9$ & 2 & 10,00 & 0 & 0 \\
\hline$>0,9$ & 2 & 10,00 & 0 & 0 \\
\hline Jumlah & 20 & $\begin{array}{c}100,0 \\
0\end{array}$ & 80 & 100,00 \\
\hline
\end{tabular}

\section{Jumlah Kredit}

Lembaga pembiayaan merupakan sumber kredit untuk memenuhi kebutuhan inputinput usahatani, petani memiliki karakteristik yang berbeda baik yang memperoleh kredit dari lembaga formal dan informal disajikan pada Tabel 6.

Tabel 6. Sebaran Jumlah Kredit Petani Mengakses Lembaga Keuangan di Kabupaten Nganjuk

\begin{tabular}{ccccc}
\hline Jumlah & $\begin{array}{c}\text { Petani Bawang } \\
\text { Merah } \\
\text { Mengakses } \\
\text { Kembaga } \\
\text { Keuangan } \\
\text { Formal }\end{array}$ & $\begin{array}{c}\text { Petani Bawang } \\
\text { Merah } \\
\text { Mengakses } \\
\text { Lembaga } \\
\text { Keuangan } \\
\text { Informal }\end{array}$ \\
\cline { 2 - 5 } & Jumlah & Jumlah & $\%$ \\
(Orang) & $\%$ & (Orang) & $\%$ \\
\hline $1-10 \mathrm{Jt}$ & 3 & 15,00 & 52 & 65,00 \\
$10-20 \mathrm{Jt}$ & 7 & 35,00 & 26 & 32,50 \\
$30-30 \mathrm{Jt}$ & 5 & 25,00 & 2 & 2,50 \\
$40-50 \mathrm{Jt}$ & 2 & 10,00 & 0 & 0 \\
$>50 \mathrm{Jt}$ & 2 & 10,00 & 0 & 0 \\
Jumlah & 1 & 5,00 & 0 & 0 \\
\hline
\end{tabular}

Berdasarkan Tabel 6, jumlah kredit yang diperoleh petani bawang merah di Kabupaten Nganjuk bervariasi kisaran 1,5 Juta sampai 60 Juta, Lembaga keuangan formal yang sering diajukan oleh petani bawang merah, diantaranya ke Bank BRI, KSP (Koperasi Simpan Pinjam), BUMDes, dengan nilai plafond kredit yang diterima bervariasi yaitu 8 juta sampai 60. sedangkan besarnya plafond pinjaman dari toko pertanian, rentenir dan tengkulak (Lembaga Keungan Informal) memperolah sebesar 1,5 juta sampai 20 juta tergantung dari pengajuan dan kesepakatan kedua belah pihak. Jenis pinjaman yang berikan oleh toko pertanian kepada petani bawang seluruhnya berbentuk barang-barang input untuk kegiatan usahataninya, namun petani yang mengakses ke rentenir dan tengkulak jenis pinjaman yang diberikan berbentuk uang.

\section{ANALISIS USAHATANI BAWANG MERAH KABUPATEN NGANJUK}

Soekartawi (1987) berpandangan lahan merupakan faktor yang sangat mempengaruhi skala usahatani dan berdampak kepada efisien atau tidaknya usaha yang dijalankan. Sejalan dengan pendapat Mubyarto (1989) lahan usahatani merupakan faktor yang sangat penting dalam kegiatan usaha dibidang pertanian. Perbedaan luas lahan dapat berpengaruh kepada input-input dan produksi yang dihasilkan.

Menurut Sukirno (2000), biaya merupakan pengorbanan yang bersumber dari ekonomi dalam bentuk uang, untuk bertujuan akan mendapatkan keuntungan kembali. Biaya produksi merupakan biaya yang dikeluarkan seseorang untuk suatu kegiatan berusahatani.

Biaya produksi merupakan semua biaya atau biaya total yang dikeluarkan petani untuk satu kali proses produksi. Penggunaan input yang dihitung dalam penelitian ini adalah penggunaan input usahatani yang mengakses modal dari lembaga keuangan formal dan lembaga keuangan informal pada tahun 2020. Jenis input yang digunakan terdiri dari benih, pupuk kandang, pupuk ZA, pupuk NPK, pupuk urea, pupuk $\mathrm{KCl}$, pestisida, dan tenaga kerja. Penggunaan input-input produksi ditingkat petani bawang merah bervariasi baik jenis, jumlah dan kualitasnya. Banyaknya penggunaan input umumnya disesuaikan dengan luas lahan yang ditanami, di samping itu kemampuan petani dalam mengakses input-input produksi dipengaruhi oleh ketersedian modal yang dimiliki petani untuk kegiatan usahatani. Hal ini mempengaruhi keputusan petani untuk menentukan 
jumlah, jenis dan kualitas input yang digunakan.

Benih yang digunakaan untuk usahatani bawang merah semuanya dibeli di toko. Umumnya jenis benih bawang merah yang digunakan petani di lokasi penelitian adalah varietas Thailand. Benih jenis ini digunakan secara luas karena diakui petani memiliki kualitas yang lebih baik dibandingkan jenis lainnya. Benih bawang merah yang umumnya digunakan di daerah penelitian minimal $864,99 \mathrm{Kg}$ per hektar, untuk petani yang mengakses kredit dari lembaga keuangan informal, sedangkan pengunanaan benih yang mengakses modal dari lembaga formal rata-rata pemakaian sebesar 999,2 $\mathrm{Kg}$ per hektar, untuk rincian rata-rata penggunaan biaya produksi usahatani bawang merah yang mengakses modal dari lembaga keuangan formal dan informal disajikan pada Tabel 7.

Tabel 7. Biaya Rata-rata Usahatani Bawang Merah per Hektar/ Musim di Kabupaten Nganjuk

\begin{tabular}{|c|c|c|c|c|}
\hline \multirow{2}{*}{$\begin{array}{l}\text { Jenis } \\
\text { Biaya }\end{array}$} & \multicolumn{2}{|c|}{$\begin{array}{l}\text { Kredit Lembaga } \\
\text { Keuangan Formal }\end{array}$} & \multicolumn{2}{|c|}{$\begin{array}{c}\text { Kredit Lembaga } \\
\text { Keuangan } \\
\text { Informal }\end{array}$} \\
\hline & $\begin{array}{l}\text { Kebu- } \\
\text { tuhan }\end{array}$ & $\mathbf{R p}$ & $\begin{array}{l}\text { Kebu- } \\
\text { tuhan }\end{array}$ & $\mathbf{R p}$ \\
\hline Benih & $992,2 \mathrm{Kg}$ & $44.649 .000,00$ & $864,99 \mathrm{Kg}$ & $40.258 .687,50$ \\
\hline \multicolumn{5}{|l|}{ Pupuk } \\
\hline Kandang & $3585 \mathrm{Kg}$ & $1.792 .500,00$ & $4756,32 \mathrm{Kg}$ & $2.378 .156,25$ \\
\hline Pupuk Urea & $260,76 \mathrm{Kg}$ & $1.173 .375,00$ & $237,81 \mathrm{Kg}$ & $990.857,82$ \\
\hline Pupuk SP 36 & $118,1 \mathrm{Kg}$ & $259.820,00$ & $83,73 \mathrm{Kg}$ & $184.222,50$ \\
\hline Pupuk KCL & $153 \mathrm{Kg}$ & $810.900,00$ & $160,32 \mathrm{Kg}$ & $972.281,25$ \\
\hline Pupuk ZA & $295,5 \mathrm{Kg}$ & $2.245 .800,00$ & $195,54 \mathrm{Kg}$ & $1.485 .990,00$ \\
\hline Pupuk NPK & $310,7 \mathrm{Kg}$ & $901.030,00$ & $256,32 \mathrm{Kg}$ & $743.306,25$ \\
\hline Pestisida & $42,4 \mathrm{Lt}$ & $7.385 .700,00$ & $39,96 \mathrm{Lt}$ & $6.570 .581,07$ \\
\hline \multicolumn{5}{|l|}{ Tenaga Kerja } \\
\hline \multicolumn{5}{|l|}{ Persiapan } \\
\hline Lahan & $27,6 \mathrm{HOK}$ & $2.047 .000,00$ & $22,68 \mathrm{HOK}$ & $1.588 .125,00$ \\
\hline Penanaman & $60,7 \mathrm{HOK}$ & $4.012 .000,00$ & $51,3 \mathrm{HOK}$ & $3.314 .625,00$ \\
\hline Pemupukan & 10,1 HOK & $736.000,00$ & 7,8 HOK & $546.000,00$ \\
\hline Penyiraman & 0,4 HOK & $728.000,00$ & 8,4 HOK & $588.000,00$ \\
\hline Panen & $36,8 \mathrm{HOK}$ & $2.244 .000,00$ & $37,65 \mathrm{HOK}$ & $2.448 .000,00$ \\
\hline \multicolumn{5}{|l|}{ Peralatan } \\
\hline Mesin Air & 1 & $226.313,50$ & 1,8 & $271.927,08$ \\
\hline Cangkul & 2,6 & $42.325,00$ & 3 & $57.522,42$ \\
\hline $\begin{array}{l}\text { Tempat Pen- } \\
\text { jemuran }\end{array}$ & 36,4 & $773.490,28$ & 26,67 & $528.891,57$ \\
\hline Terpal & 3,5 & $100.888,88$ & 3 & $56.591,67$ \\
\hline Spayer & 2,5 & $188.500,00$ & 3 & $217.358,49$ \\
\hline Parang/Arit & 2,8 & $38.100,00$ & 3,03 & $47.543,13$ \\
\hline Pajak Lahan & & $69.133,34$ & & $63.575,01$ \\
\hline Sewa Lahan & & $2.239 .166,66$ & & $1.509 .473,67$ \\
\hline Biaya Irigasi & & $618.000,00$ & & $624.000,00$ \\
\hline Jumlah & & $73.281 .042,66$ & & $65.445 .715,68$ \\
\hline
\end{tabular}

Berdasarkan Tabel 7, rata-rata biaya usahatani bawang merah di Kabupaten Nganjuk yang mengakses modal dari lem- baga keuangan formal lebih besar dibandingkan dengan rata-rata biaya produksi bawang merah yang mengakses modal dari lembaga keuangan informal. Biaya usahatani bawang merah terdiri dari biaya tetap dan biaya tidak tetap. Biaya tetap merupakan biaya yang besar kecilnya tidak dipengaruhi oleh besar kecilnya produksi sedangkan untuk biaya variabel adalah biaya yang besar kecilnya dipengaruhi oleh besar kecilnya produksi dan sifatnya habis dalam satu kali proses produksi.

Total biaya variabel usahatani bawang yang mengakses modal dari lembaga keuangan formal sebesar Rp.68.985.125,00 dan total biaya variabel untuk usahatani bawang merah mengakses modal dari lembaga keuangan informal sebesar Rp.62.068.832,64. Biaya variabel terdiri dari pembelian benih, pupuk dan tenaga kerja. Biaya tetap pada usahatani bawang merah mengakses lembaga formal lebih besar dari usahatani bawang merah yang mengakses lembaga keuangan informal dengan nilai masing-masing Rp.4.295.917,66 dan Rp.3.376.883,04. Biaya yang paling besar yaitu biaya sewa lahan. Hal ini dikarenakan biaya sewa lahan di Kabupaten Nganjuk bila dihitung rata-rata per musim tanam sebesar Rp.2.239.166,66, untuk usahatani yang mengakses kredit ke lembaga keuangan formal dan sebesar Rp.1.509.473,67 petani yang mengakses kredit ke lembaga keuangan informal.

Biaya usahatani bawang merah sangat dipengaruhi oleh biaya pembelian benih, pupuk dan tenaga kerja yang digunakan serta biaya sewa lahan. Biaya pembelian benih merupakan komponen biaya yang paling tinggi baik untuk usahatani bawang merah yang mengakses modal dari lembaga keuangan formal dan petani yang mengakses modal dari lembaga keuangan informal yang masing-masing mencapai $60,93 \%$ dan $61,51 \%$ dari total masing-masing biaya. Harga benih dari masing-masing bawang merah rata-rata yakni Rp.45.000,00.Tingginya biaya benih tersebut dikarenakan benih yang dipakai merupakan benih yang sering digunakan oleh petani bawang merah di Kabupaten Nganjuk. 
Proporsi biaya terbesar selanjutnya yaitu biaya tenaga kerja dengan rata-rata sebesar Rp.9.767.000,00, untuk usahatani yang mengakses ke lembaga keuangan formal, sedangkan usahatani yang mengakses ke informal sebesar Rp.8.484.750,00. Upah buruh tani di Kabupaten Nganjuk sebesar Rp.70.000 untuk laki-laki dan upah prempuan sebesar Rp.60.000 per hari kerja. Menurut Hasan (2019) tingginya biaya sarana produksi, terutama disebabkan oleh tingginya harga bibit selama semusim tanam. Dilihat dari struktur biayanya, komponen biaya terbesar adalah pada benih $(44,8 \%)$ diikuti tenaga kerja $(26,7 \%)$.

\section{Penerimaan}

Penerimaan merupakan refleksi dari kinerja produksi dan dinamika harga, artinya besarnya penerimaan ditentukan oleh dua aspek yaitu aspek produksi dan aspek harga, dengan kata lain penerimaan bisa meningkat apabila produksi meningkat walaupun harga tetap, atau harga meningkat dan produksi tetap atau kedua aspek tersebut meningkat.

Pada musim tanam, panen bawang merah bisa mencapai 13-14 Ton/ Ha dengan tingkat harga yang bervariasi tergantung pada kondisi pasar dan kualitas hasil. Berikut rincian hasil penerimaan hasil usahatani bawang merah dituangkan pada Tabel 8 .

Tabel 8. Rata-rata Penerimaan Usahatani Bawang Merah per Musim di Kabupaten Nganjuk

\begin{tabular}{lcc}
\hline Uraian & $\begin{array}{c}\text { Usahatani } \\
\text { Bawang Merah } \\
\text { Mengakses } \\
\text { Lembaga } \\
\text { Keuangan } \\
\text { Formal }\end{array}$ & $\begin{array}{c}\text { Usahatani } \\
\text { Bawang Merah } \\
\text { Mengakses } \\
\text { Lembaga }\end{array}$ \\
& $\begin{array}{c}\text { Keuangan } \\
\text { Informal }\end{array}$ \\
\hline Produksi $(\mathrm{Kg})$ & $6.708,00$ & $4.980,09$ \\
Harga $(\mathrm{Rp} / \mathrm{Kg})$ & $21.885,00$ & $21.840,63$ \\
\hline Penerimaan (Rp) & $\mathbf{1 4 6 . 8 0 4 . 5 8 0 , 0 0}$ & $\mathbf{1 0 8 . 7 6 8 . 3 0 3 , 0 6}$ \\
\hline
\end{tabular}

Harga sangat ditentukan oleh berbagai faktor, antara lain kualitas bawang merah yang dihasilkan, tujuan penjualan dan ketersediaan bawang merah di pasar. Kelemahan mekanisme harga produk pertanian adalah harga yang jatuh saat panen raya, karena supplay terlalu banyak. Rata-rata harga ditingkat petani di Kabupaten Nganjuk pada bulan Juni sebesar Rp.19.800 sampai Rp.22.500 per kg, tinggi harga bawang merah ditingkat petani disebabkan oleh petani menanam bawang merah bukan pada masa tanam raya, sehingga jumlah yang menanam bawang merah masih tergolong sedikit. Sejalan dengan penelitian Waryanto, dkk (2014) harga jual bawang merah dari petani sebesar Rp.25.053 per kg, tinggi harga jual disebabkan oleh petani menanam bukan pada saat tanam raya. Rata-rata jumlah produksi usahatani bawang merah yang mengakses modal dari lembaga keuangan formal sebesar $6.708 \mathrm{~kg}$ per hektar per musim tanam dan jumlah rata-rata produksi bawang usahatani bawang merah yang mengakses lembaga keuangan informal sebesar 4.980,09 $\mathrm{kg}$ per hektar per musim tanam, perbedaan jumlah produksi diduga disebabkan perbedaan kuantitas pengunaan input antara usahatani bawang merah yang mengakses modal keuangan formal dan lembaga keuangan informal.

Harga dan produksi usahatani bawang merah mendapatkan penerimaan sebesar Rp.146.804.580,00 per hektar per musim tanam, untuk usahatani bawang merah yang mengakses lembaga keuangan formal, sedangkan usahatani bawang merah yang mengakses lembaga keuangan informal dengan total penerimaan sebesar Rp.108.768.303,06 per hektar per musim tanam. Perbedaan penerimaan disebabkan oleh jumlah produksi usahatani bawang jumlah produksi yang dihasilkan diantara kedua usahatani berdasarkan akses modal.

\section{Pendapatan}

Menurut Santika (1999) setiap akan melakukan kegiatan usahatani, petani tentunya akan selalu berpikir apakah usahanya menguntungkan atau tidak. Perhitungan analisis usahatani merupakan salah satu tolak ukur untuk menghitung keuntungan tersebut, untuk mengetahui lebih jelas prospek usahatani bawang merah ada baiknya mengetahui 
perhitungan biaya dan untung ruginya, berikut ini analisis pendapatan usahatani bawang merah Kabupaten Nganjuk disajikan pada Tabel 9.

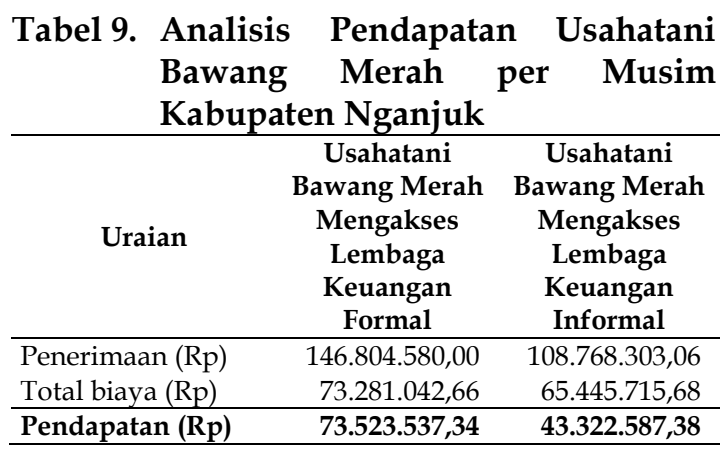

Berdasarkan Tabel 9, menunjukkan bahwa pendapatan petani bawang merah dengan nilai rata-rata pendapatan usahatani bawang merah di Kabupaten Nganjuk sebesar Rp.73.523.537,34, untuk usahatani bawang merah yang mengakses lembaga keuangan formal dan usahatani yang mengakses lembaga keuangan informal dengan jumlah pendapatan sebesar Rp.43.322.587,38. Berdasarkan hasil penelitian Fauzan (2014) rata-rata pendapatan usahatani bawang merah di Kabupaten Nganjuk sebesar Rp.35.294.540. Perbedaan jumlah pendapatan antara petani mengakses lembaga keuangan formal dan informal, dikarenakan harga jual bawang merah dan modal yang diperoleh dari lembaga keuangan, untuk memenuhi kebutuhan input-input kegiatan usahatani bawang merah. Menurut Nurjati, dkk (2018) penggunaan input berpengaruh nyata terhadap produksi terhadap produksi bawang merah.

Peningkatan penggunaan input kegiatan usahatani membutuhkan modal. Hal ini sejalan dengan Hendayana, dkk (2009) permasalahan mendasar dihadapi petani yaitu lemahnya permodalan sementara aksesibilitas terhadap sumber permodalan, pasar dan teknologi. Rendahnya penguasaan modal menyebabkan tingkat adopsi teknologi ditingkat petani menjadi rendah yang berdampak kepada rendahnya produktivitas usahatani (Omobolanle dan Olu, 2006).

Pendapatan usahatani diperoleh dari selisih antara penerimaan dan total biaya, untuk mengetahui pengaruh perbedaan pendapatan antara usatani bawang merah yang mengakses lembaga keuangan formal dan usahatani bawang merah yang mengakses lembaga keuangan informal terhadap pendapatan.

Hasil analisis p-value untuk perbedaan pendapatan usahatani bawang merah yang mengakses lembaga keuangan formal dan usahatani bawang merah yang mengakses lembaga keuangan infromal yaitu 0,027. Jika dibandingkan dengan taraf signifikan 5\% maka p-value bernilai lebih kecil sehingga dapat disimpulkan bahwa terdapat pengaruh yang nyata antara usahatani bawang merah yang mengakses lembaga keuangan formal dan informal

\section{KESIMPULAN DAN SARAN}

\section{KESIMPULAN}

Berdasarkan hasil penelitian dan pembahasan, maka dapat disimpulkan yaitu:

1. Rata-rata pendapatan usahatani bawang merah yang mengakses lembaga keuangan formal sebesar Rp 73.523.537,34 per hektar per musim tanam, sedangkan rata-rata pendapatan petani bawang merah yang mengakses lembaga keuangan informal sebesar $\mathrm{Rp} 43.322 .587,38$ per hektar per musim tanam. Perbedaan pendapatan disebabkan hasil produksi antara usahatani bawang merah yang mengakses keuangan formal dan informal.

2. Berdasarkan analisis perbedaan (Komparasi) pendapatan usahatani bawang merah yang mengakses kredit ke lembaga keuangan formal dan informal dengan uji beda dengan hasil $F_{\text {hitung }}$ lebih besar dari $\mathrm{Ft}_{\text {abel }}$ dan $\mathrm{T}_{\text {hitung }}$ lebih besar dari $\mathrm{Tt}_{\text {abel }}$ dengan signifikan 0,027, dengan keputusan tolak Ho terima H1, artinya terdapat perbedaan nyata antara usatani bawang merah yang mengakses kredit ke lembaga keuangan formal dan informal. 


\section{SARAN}

1. Bagi petani, upaya meminimalkan besarnya biaya input produksi bawang merah diharapkan mengurangi penggunaan pupuk yang berlebihan, sehingga modal yang digunakan untuk biaya produksi dapat dimanfaatkan secara optimal.

2. Bagi Pemerintah, mempermudah prosedur pengajuan kredit, sehingga petani dapat mengajukan kredit secara merata dan meningkatkan jumlah kredit untuk modal usahatani.

\section{DAFTAR PUSTAKA}

Basuki, RS. 2014. Indentiffikasi Permasalahan dan Analisis Usahatani Bawang Merah di Dataran Tinggi pada Musim Hujan di Kabupaten Majalengka. J. Hort. Vol. 24 No. 3.

(BPS). Badan Pusat Statistik Provinsi Jawa Timur. 2016. Analisis Data Bawang Merah dan Cabai Provinsi JawaTimur. BPS Provinsi Jawa Timur. Surabaya.

(BPS). Badan Pusat Statistik. 2018. Kabupaten Nganjuk Dalam Angka. CV. Azka Putra Pratama. Nganjuk.

Dinas Penanam Modal dan Pelayanan Terpadu. 2018. Satu Pintu Kabupaten Nganjuk. Kabupaten Nganjuk.

Dinas Pertanian Kabupaten Nganjuk. 2018. Rencana Strategis Pembangunan Pertanian Kabupaten Nganjuk Tahun 2014-2018. Dinas Pertanian Daerah Kabupaten Nganjuk. Jawa Timur.

Fauzan, Muhammad. 2014. Profitabilitas Dan Efisiensi Teknis Usahatani Bawang Merah di Kabupaten Bantul dan Kabupaten Nganjuk. Jurnal SEPA : Vol. 11 No.1.

Hasan, Fuad. 2019. Efisiensi Keuntungan Usahatani Bawang di Kabupaten Nganjuk : Pendekatan Stokastik Frontier. Jurnal Social Economic of Agriculture, Volume 8, Nomor 1, April , hlm 94-103.
Hendayana, R., S. Bustaman, N. Sunandar., E. Jamarl. 2009. Petunjuk Pelaksanaan Pembentukan dan Pengembangan Lembaga Keuangan Mikro Agribisnis. Balai Besar Pengakajian dan Pengembangan Teknologi Pertanian. Badan Penelitian dan Pengembangan Pertanian. Kementerian Pertanian. Bogor.

Kementerian Pedagangan. 2020. Perkembangan Ekspor Impor Bawang di Indonesia Tahun 2014-2019. Kementerian Perdagangan Republik Indonesia. Jakarta.

Mosher, A.T. 1987. Menggerakkan dan Membangun Pertanian: Syarat-syarat Pokok Pembangunan dan Modernisasi. Jakarta: CV. Yasaguna.

Mubyarto.1989. Pengantar Ilmu Ekonomi Pertanian, Edisi III. Lembaga Penelitian Pendidikan dan Penerangan Ekonomi dan Sosial. Yogyakarta.

Nurjati, E., Fahmi, I., Jahroh, S. 2018. Analisis Efisiensi Produksi Bawang Merah di Kabupaten Pati dengan Fungsi Produksi Frontier Stokastik Cobb-Douglas. Jurnal Agro Ekonomi, Vol 36. No.1.

Omobolanle, O.L, S. Olu. 2005. Adoption Behaviour Of Famers in Southwest, Nigeria : The Case of Soybean Farmers. Journal Central European of Agriculture. Vol 6 (4). Hal 415-426.

Rusli, Said. 2012. Pengantar Ilmu Kependudukan. Jakarta: LP3ES.

Santika, A. 1999. Agribisnis Cabai. Penebar Swadaya. Jakarta.

Soekartawi.2006. Analisis Usahatani. Jakarta. Universtas Indonesia.

Soekartawi, 1987. Prinsip Dasar Ekonomi Pertanian Teori dan Aplikasinya.PT. Rajawali Press. Jakarta.

Suratiyah, Ken.2006. Ilmu Usahatani. Penebar Swadaya. Jakarta. 
Sukirno, Sadono. 2000. Makro Ekonomi Modern. Penerbit PT. Raja Grafindo Perkasa, Jakarta.

Waryanto B, Chozin MA, Dadang, Intan EK. 2014. Analisis efisiensi teknis, efisiensi ekonomis dan daya saing pada usahatani bawang merah di Kabupaten NganjukJawa Timur: suatu pendekatan ekonometrik dan PAM. Inform Pertan. 23(2):147- 158.

Wati, D, R., Nuryarto, N., Anggraeni, L. 2014. Akses dan Dampak Kredit Mikro Terhadap Produksi Padi Organik di Kabupaten Bogor. Jurnal Ekonomi dan Kebijakan Pembangunan, Hal. 75-94.

Yunita. 2011. Strategi Peningkatan Kapasitas Petani Padi Sawah Lebak Menuju Ketahanan Pagan Rumah Tangga di Kabupaten Ogan Ilir dan Ogan Kemering Ilir Provinsi Sumatera Selatan. (Disertasi). Sekolah Pascasarjana Institut Pertanian Bogor. Bogor.

Wulandari, E., Meuwissen, M. P., Karmana, M. H., \& Lansink, A. G. O. 2017. Access to Finance from Different Finance Provider Types: Farmer Knowledge of the Requirements. PloS one, 12: 9, September 2017. 
Lampiran 1. Karakteristik Responden Petani Bawang Merah Mengakses Lembaga Keuangan Formal

\begin{tabular}{ccrrccr}
\hline Responden & $\begin{array}{c}\text { Umur } \\
\text { petani }\end{array}$ & Pendidikan & Pengalaman & $\begin{array}{c}\text { Jumlah } \\
\text { tanggungan } \\
\text { keluarga }\end{array}$ & Luas Lahan & Jumlah Kredit \\
\hline 1 & 41 & 9 & 20 & 4 & 0,52 & 20.000 .000 \\
2 & 40 & 12 & 15 & 3 & 0,84 & 50.000 .000 \\
3 & 53 & 6 & 24 & 5 & 0,42 & 15.000 .000 \\
4 & 46 & 9 & 21 & 3 & 0,27 & 10.000 .000 \\
5 & 50 & 6 & 30 & 6 & 0,25 & 10.000 .000 \\
6 & 42 & 9 & 17 & 4 & 0,35 & 12.000 .000 \\
7 & 39 & 9 & 12 & 2 & 0,49 & 25.000 .000 \\
8 & 49 & 6 & 7 & 4 & 0,35 & 12.000 .000 \\
9 & 51 & 6 & 25 & 6 & 0,60 & 30.000 .000 \\
10 & 37 & 9 & 6 & 3 & 0,35 & 12.000 .000 \\
11 & 40 & 6 & 14 & 4 & 0,37 & 15.000 .000 \\
12 & 49 & 9 & 18 & 3 & 0,25 & 8.000 .000 \\
13 & 47 & 9 & 15 & 4 & 0,42 & 12.000 .000 \\
14 & 43 & 16 & 7 & 4 & 0,60 & 25.000 .000 \\
15 & 40 & 6 & 5 & 3 & 1,00 & 50.000 .000 \\
16 & 42 & 6 & 10 & 4 & 0,49 & 25.000 .000 \\
17 & 48 & 9 & 6 & 3 & 0,56 & 30.000 .000 \\
18 & 43 & 9 & 15 & 3 & 0,70 & 40.000 .000 \\
19 & 55 & 6 & 35 & 7 & 0,60 & 35.000 .000 \\
20 & 49 & 16 & 11 & 5 & 1,00 & 60.000 .000 \\
\hline
\end{tabular}

Lampiran 2. Karakteristik Responden Petani Bawang Merah yang Mengakses Lembaga Keuangan Informal

\begin{tabular}{|c|c|c|c|c|c|c|}
\hline Responden & $\begin{array}{l}\text { Umur } \\
\text { Petani }\end{array}$ & Pendidikan & Pengalaman & $\begin{array}{c}\text { Jumlah } \\
\text { Tanggungan } \\
\text { Keluarga }\end{array}$ & Luas Lahan & Jumlah Kredit \\
\hline 1 & 48 & 9 & 12 & 4 & 0,112 & 3.725 .000 \\
\hline 2 & 40 & 9 & 8 & 3 & 0,35 & 5.300 .000 \\
\hline 3 & 55 & 6 & 22 & 6 & 0,21 & 4.250 .000 \\
\hline 4 & 50 & 6 & 30 & 5 & 0,27 & 6.150 .000 \\
\hline 5 & 50 & 6 & 24 & 5 & 0,25 & 4.500 .000 \\
\hline 6 & 48 & 9 & 12 & 3 & 0,21 & 5.350 .000 \\
\hline 7 & 54 & 6 & 25 & 4 & 0,47 & 13.640 .000 \\
\hline 8 & 43 & 9 & 8 & 3 & 0,35 & 8.500 .000 \\
\hline 9 & 51 & 6 & 16 & 6 & 0,35 & 7.000 .000 \\
\hline 10 & 55 & 6 & 30 & 7 & 0,14 & 4.600 .000 \\
\hline 11 & 40 & 12 & 5 & 3 & 0,35 & 10.200 .000 \\
\hline 12 & 52 & 6 & 19 & 5 & 0,14 & 5.300 .000 \\
\hline 13 & 54 & 9 & 14 & 4 & 0,14 & 3.150 .000 \\
\hline 14 & 41 & 12 & 12 & 3 & 0,46 & 17.420 .000 \\
\hline 15 & 35 & 12 & 6 & 3 & 0,21 & 5.350 .000 \\
\hline 16 & 44 & 9 & 11 & 4 & 0,26 & 4.300 .000 \\
\hline 17 & 41 & 9 & 4 & 3 & 0,26 & 3.100 .000 \\
\hline 18 & 55 & 6 & 32 & 5 & 0,35 & 10.000 .000 \\
\hline 19 & 53 & 6 & 25 & 6 & 0,26 & 6.500 .000 \\
\hline 20 & 48 & 9 & 10 & 4 & 0,42 & 12.300 .000 \\
\hline 21 & 56 & 6 & 25 & 6 & 0,35 & 9.500 .000 \\
\hline 22 & 47 & 12 & 10 & 4 & 0,42 & 13.400 .000 \\
\hline 23 & 48 & 9 & 12 & 4 & 0,46 & 15.000 .000 \\
\hline 24 & 51 & 6 & 20 & 5 & 0,36 & 9.000 .000 \\
\hline 25 & 57 & 6 & 23 & 6 & 0,36 & 11.400 .000 \\
\hline 26 & 50 & 6 & 20 & 6 & 0,175 & 2.500 .000 \\
\hline 27 & 54 & 6 & 15 & 7 & 0,35 & 6.500 .000 \\
\hline 28 & 41 & 12 & 9 & 4 & 0,35 & 10.000 .000 \\
\hline 29 & 48 & 12 & 6 & 3 & 0,29 & 6.800 .000 \\
\hline 30 & 40 & 9 & 12 & 4 & 0,35 & 15.400 .000 \\
\hline
\end{tabular}




\begin{tabular}{|c|c|c|c|c|c|c|}
\hline Responden & $\begin{array}{l}\text { Umur } \\
\text { Petani }\end{array}$ & Pendidikan & Pengalaman & $\begin{array}{c}\text { Jumlah } \\
\text { Tanggungan } \\
\text { Keluarga }\end{array}$ & Luas Lahan & Jumlah Kredit \\
\hline 31 & 56 & 6 & 10 & 6 & 0,25 & 9.650 .000 \\
\hline 32 & 37 & 12 & 4 & 4 & 0,29 & 9.000 .000 \\
\hline 33 & 40 & 9 & 7 & 4 & 0,35 & 13.150 .000 \\
\hline 34 & 47 & 9 & 9 & 4 & 0,25 & 7.500 .000 \\
\hline 35 & 51 & 6 & 14 & 6 & 0,42 & 15.000 .000 \\
\hline 36 & 40 & 9 & 7 & 4 & 0,35 & 12.500 .000 \\
\hline 37 & 48 & 12 & 14 & 5 & 0,14 & 1.500 .000 \\
\hline 38 & 60 & 6 & 34 & 7 & 0,29 & 7.500 .000 \\
\hline 39 & 61 & 6 & 40 & 5 & 0,35 & 10.000 .000 \\
\hline 40 & 53 & 6 & 20 & 6 & 0,29 & 8.500 .000 \\
\hline 41 & 38 & 9 & 8 & 4 & 0,14 & 2.500 .000 \\
\hline 42 & 41 & 12 & 6 & 3 & 0,35 & 10.200 .000 \\
\hline 43 & 42 & 9 & 9 & 4 & 0,29 & 7.000 .000 \\
\hline 44 & 45 & 9 & 5 & 4 & 0,29 & 9.000 .000 \\
\hline 45 & 55 & 6 & 13 & 5 & 0,35 & 8.500 .000 \\
\hline 46 & 48 & 12 & 6 & 4 & 0,43 & 9.600 .000 \\
\hline 47 & 41 & 9 & 12 & 3 & 0,14 & 2.300 .000 \\
\hline 48 & 45 & 9 & 7 & 3 & 0,29 & 8.000 .000 \\
\hline 49 & 60 & 6 & 30 & 6 & 0,70 & 16.000 .000 \\
\hline 50 & 33 & 12 & 4 & 4 & 0,52 & 17.600 .000 \\
\hline 51 & 50 & 6 & 18 & 5 & 0,52 & 18.500 .000 \\
\hline 52 & 65 & 6 & 17 & 6 & 0,43 & 12.500 .000 \\
\hline 53 & 40 & 9 & 12 & 4 & 0,29 & 10.200 .000 \\
\hline 54 & 48 & 9 & 15 & 4 & 0,21 & 5.900 .000 \\
\hline 55 & 39 & 9 & 6 & 3 & 0,30 & 15.000 .000 \\
\hline 56 & 42 & 9 & 8 & 4 & 0,35 & 9.500 .000 \\
\hline 57 & 50 & 6 & 17 & 6 & 0,35 & 8.000 .000 \\
\hline 58 & 58 & 6 & 24 & 5 & 0,42 & 11.350 .000 \\
\hline 59 & 56 & 6 & 19 & 5 & 0,175 & 3.500 .000 \\
\hline 60 & 50 & 6 & 20 & 5 & 0,30 & 7.500 .000 \\
\hline 61 & 54 & 6 & 10 & 4 & 0,35 & 10.500 .000 \\
\hline 62 & 43 & 9 & 14 & 4 & 0,35 & 12.500 .000 \\
\hline 63 & 50 & 9 & 19 & 6 & 0,21 & 5.600 .000 \\
\hline 64 & 45 & 12 & 12 & 4 & 0,30 & 10.000 .000 \\
\hline 65 & 51 & 6 & 25 & 5 & 0,14 & 2.500 .000 \\
\hline 67 & 30 & 12 & 6 & 3 & 0,30 & 11.000 .000 \\
\hline 68 & 55 & 6 & 19 & 5 & 0,30 & 10.000 .000 \\
\hline 69 & 51 & 6 & 23 & 5 & 0,42 & 11.200 .000 \\
\hline 70 & 48 & 9 & 9 & 4 & 0,21 & 5.100 .000 \\
\hline 71 & 45 & 9 & 14 & 4 & 0,30 & 9.000 .000 \\
\hline 72 & 50 & 6 & 21 & 7 & 0,21 & 3.450 .000 \\
\hline 73 & 47 & 9 & 18 & 5 & 0,14 & 2.500 .000 \\
\hline 74 & 55 & 6 & 20 & 5 & 0,175 & 3.250 .000 \\
\hline 75 & 49 & 9 & 6 & 4 & 0,52 & 22.350 .000 \\
\hline 76 & 36 & 9 & 10 & 3 & 0,42 & 14.500 .000 \\
\hline 77 & 41 & 9 & 11 & 4 & 0,42 & 12.000 .000 \\
\hline 78 & 39 & 6 & 8 & 4 & 0,35 & 9.500 .000 \\
\hline 79 & 54 & 6 & 12 & 5 & 0,46 & 10.200 .000 \\
\hline 80 & 47 & 6 & 7 & 4 & 0,52 & 20.500 .000 \\
\hline
\end{tabular}


Lampiran 3. Pendapatan Usahatani Bawang Kabupaten Nganjuk yang Mengakses Lembaga Keuangan Formal

\begin{tabular}{ccccrr}
\hline Sampel & Total Biaya (Rp) & $\begin{array}{c}\text { Jumlah } \\
\text { Produksi (Kg) }\end{array}$ & Harga (Rp) & Penerimaan (Rp) & Pendapatan (Rp) \\
\hline 1 & $38.381 .277,78$ & 3.582 & 22000 & $78.804 .000,00$ & $40.422 .722,22$ \\
2 & $55.722 .476,19$ & 6.300 & 21500 & $135.450 .000,00$ & $79.727 .523,81$ \\
3 & $24.719 .250,00$ & 3.200 & 22000 & $70.400 .000,00$ & $45.680 .750,00$ \\
4 & $17.170 .750,00$ & 2.400 & 22000 & $52.800 .000,00$ & $35.629 .250,00$ \\
5 & $16.039 .875,00$ & 2.000 & 22000 & $44.000 .000,00$ & $27.960 .125,00$ \\
6 & $19.600 .680,56$ & 1.800 & 22000 & $39.600 .000,00$ & $19.999 .319,44$ \\
7 & $26.263 .222,22$ & 3.655 & 21700 & $79.313 .500,00$ & $53.050 .277,78$ \\
8 & $22.397 .073,41$ & 1.650 & 22000 & $36.300 .000,00$ & $13.902 .926,59$ \\
9 & $42.949 .250,00$ & 3.200 & 22000 & $70.400 .000,00$ & $27.450 .750,00$ \\
10 & $20.695 .208,33$ & 1.500 & 22000 & $33.000 .000,00$ & $12.304 .791,67$ \\
11 & $23.493 .638,89$ & 1.900 & 22000 & $41.800 .000,00$ & $18.306 .361,11$ \\
12 & $20.447 .315,48$ & 1.300 & 22000 & $28.600 .000,00$ & $8.152 .684,52$ \\
13 & $26.451 .666,67$ & 2.000 & 22000 & $44.000 .000,00$ & $17.548 .333,33$ \\
14 & $42.099 .214,29$ & 3.800 & 21800 & $82.840 .000,00$ & $40.740 .785,71$ \\
15 & $79.021 .083,33$ & 7.318 & 21700 & $158.800 .600,00$ & $79.779 .516,67$ \\
16 & $39.275 .111,11$ & 2.300 & 22000 & $50.600 .000,00$ & $11.324 .888,89$ \\
17 & $41.897 .027,78$ & 3.900 & 22000 & $85.800 .000,00$ & $43.902 .972,22$ \\
18 & $51.013 .194,44$ & 4.000 & 21500 & $86.000 .000,00$ & $34.986 .805,56$ \\
19 & $44.307 .111,11$ & 3.150 & 22000 & $69.300 .000,00$ & $24.992 .888,89$ \\
20 & $80.866 .000,00$ & 8.125 & 21500 & $174.687 .500,00$ & $93.821 .500,00$ \\
\hline
\end{tabular}

Lampiran 4. Pendapatan Usatani Bawang Kabupaten Nganjuk yang Mengakses Lembaga Keuangan Informal

\begin{tabular}{crcrrr}
\hline Sampel & Total Biaya (Rp) & $\begin{array}{c}\text { Jumlah } \\
\text { Produksi (Kg) }\end{array}$ & Harga (Rp) & Penerimaan (Rp) & Pendapatan (Rp) \\
\hline 1 & $10.145 .916,67$ & 950 & 22000 & $20.900 .000,00$ & $10.754 .083,33$ \\
2 & $16.892 .138,89$ & 1.980 & 21800 & $43.164 .000,00$ & $26.271 .861,11$ \\
3 & $11.911 .833,33$ & 1.600 & 21500 & $34.400 .000,00$ & $22.488 .166,67$ \\
4 & $14.066 .750,00$ & 1.600 & 21700 & $34.720 .000,00$ & $20.653 .250,00$ \\
5 & $12.086 .350,00$ & 1.200 & 22000 & $26.400 .000,00$ & $14.313 .650,00$ \\
6 & $11.412 .550,00$ & 1.150 & 22000 & $25.300 .000,00$ & $13.887 .450,00$ \\
7 & $22.885 .500,00$ & 2.450 & 21400 & $52.430 .000,00$ & $29.544 .500,00$ \\
8 & $18.519 .188,89$ & 1.750 & 22000 & $38.500 .000,00$ & $19.980 .811,11$ \\
9 & $16.591 .138,89$ & 1.500 & 22000 & $33.000 .000,00$ & $16.408 .861,11$ \\
10 & $9.606 .055,56$ & 800 & 22000 & $17.600 .000,00$ & $7.993 .944,44$ \\
11 & $18.564 .527,78$ & 1.750 & 22000 & $38.500 .000,00$ & $19.935 .472,22$ \\
12 & $9.121 .611,11$ & 565 & 22000 & $12.430 .000,00$ & $3.308 .388,89$ \\
13 & $8.995 .555,56$ & 455 & 22500 & $10.237 .500,00$ & $1.241 .944,44$ \\
14 & $27.881 .027,78$ & 2.930 & 21800 & $63.874 .000,00$ & $35.992 .972,22$ \\
15 & $12.223 .666,67$ & 1.150 & 22000 & $25.300 .000,00$ & $13.076 .333,33$ \\
16 & $14.110 .055,56$ & 930 & 22000 & $20.460 .000,00$ & $6.349 .944,44$ \\
17 & $13.532 .388,89$ & 1.100 & 22000 & $24.200 .000,00$ & $10.667 .611,11$ \\
18 & $18.359 .222,22$ & 1.250 & 22000 & $27.500 .000,00$ & $9.140 .777,78$ \\
19 & $14.891 .566,67$ & 1.340 & 22000 & $29.480 .000,00$ & $14.588 .433,33$ \\
20 & $26.666 .472,22$ & 2.456 & 21500 & $52.804 .000,00$ & $26.137 .527,78$ \\
21 & $21.050 .555,56$ & 2.100 & 21700 & $45.570 .000,00$ & $24.519 .444,44$ \\
22 & $24.688 .833,33$ & 2.451 & 21500 & $52.696 .500,00$ & $28.007 .666,67$ \\
23 & $25.752 .888,89$ & 2.905 & 21800 & $63.329 .000,00$ & $37.576 .111,11$ \\
24 & $21.777 .333,33$ & 1.450 & 21900 & $31.755 .000,00$ & $9.977 .666,67$ \\
25 & $24.119 .666,67$ & 1.250 & 22000 & $27.500 .000,00$ & $3.380 .333,33$ \\
26 & $9.784 .486,11$ & 900 & 22500 & $20.250 .000,00$ & $10.465 .513,89$ \\
27 & $21.773 .861,11$ & 1.345 & 22000 & $29.590 .000,00$ & $7.816 .138,89$ \\
28 & $23.768 .972,22$ & 1.960 & 21500 & $42.140 .000,00$ & $18.371 .027,78$ \\
29 & $17.435 .416,67$ & 1.100 & 22000 & $24.200 .000,00$ & $6.764 .583,33$ \\
30 & $24.704 .972,22$ & 1.259 & 22000 & $27.698 .000,00$ & $2.993 .027,78$ \\
\hline & & & & & \\
\hline
\end{tabular}




\begin{tabular}{|c|c|c|c|c|c|}
\hline Sampel & Total Biaya (Rp) & $\begin{array}{c}\text { Jumlah } \\
\text { Produksi (Kg) }\end{array}$ & Harga (Rp) & Penerimaan (Rp) & Pendapatan (Rp) \\
\hline 31 & $18.432 .500,00$ & 998 & 22000 & $21.956 .000,00$ & $3.523 .500,00$ \\
\hline 32 & $17.557 .333,33$ & 1.050 & 22000 & $23.100 .000,00$ & $5.542 .666,67$ \\
\hline 33 & $22.149 .138,89$ & 1.700 & 21800 & $37.060 .000,00$ & $14.910 .861,11$ \\
\hline 34 & $16.596 .388,89$ & 1.155 & 22000 & $25.410 .000,00$ & 8.813.611,11 \\
\hline 35 & $27.223 .000,00$ & 2.905 & 19800 & $57.519 .000,00$ & $30.296 .000,00$ \\
\hline 36 & $23.626 .255,56$ & 2.600 & 21500 & $55.900 .000,00$ & $32.273 .744,44$ \\
\hline 37 & $9.541 .555,56$ & 700 & 22500 & $15.750 .000,00$ & $6.208 .444,44$ \\
\hline 38 & $19.831 .872,22$ & 950 & 22000 & $20.900 .000,00$ & 1.068.127,78 \\
\hline 39 & $26.509 .305,56$ & 1.455 & 22000 & $32.010 .000,00$ & $5.500 .694,44$ \\
\hline 40 & $19.635 .833,33$ & 1.300 & 22000 & $28.600 .000,00$ & $8.964 .166,67$ \\
\hline 41 & $9.472 .646,03$ & 890 & 22500 & $20.025 .000,00$ & $10.552 .353,97$ \\
\hline 42 & $24.472 .777,78$ & 1.450 & 22000 & $31.900 .000,00$ & 7.427.222,22 \\
\hline 43 & $19.967 .972,22$ & 1.100 & 21600 & $23.760 .000,00$ & 3.792.027,78 \\
\hline 44 & $21.321 .466,67$ & 1.450 & 21700 & $31.465 .000,00$ & $10.143 .533,33$ \\
\hline 45 & $19.911 .329,37$ & 1.750 & 21600 & $37.800 .000,00$ & $17.888 .670,63$ \\
\hline 46 & 24.761.722,22 & 1.950 & 21800 & $42.510 .000,00$ & $17.748 .277,78$ \\
\hline 47 & $9.954 .972,22$ & 800 & 22000 & $17.600 .000,00$ & $7.645 .027,78$ \\
\hline 48 & $20.613 .583,33$ & 950 & 22000 & $20.900 .000,00$ & $286.416,67$ \\
\hline 49 & $42.846 .944,44$ & 4.000 & 21500 & $86.000 .000,00$ & $43.153 .055,56$ \\
\hline 50 & $33.096 .972,22$ & 3.800 & 21500 & $81.700 .000,00$ & $48.603 .027,78$ \\
\hline 51 & $32.507 .111,11$ & 3.000 & 21500 & $64.500 .000,00$ & $31.992 .888,89$ \\
\hline 52 & $30.260 .583,33$ & 2.780 & 21350 & $59.353 .000,00$ & $29.092 .416,67$ \\
\hline 53 & $20.899 .172,22$ & 1.454 & 21500 & $31.261 .000,00$ & $10.361 .827,78$ \\
\hline 54 & $16.545 .444,44$ & 1.015 & 22000 & $22.330 .000,00$ & $5.784 .555,56$ \\
\hline 55 & $25.651 .055,56$ & 1.900 & 21500 & $40.850 .000,00$ & $15.198 .944,44$ \\
\hline 56 & $22.217 .194,44$ & 1.350 & 22000 & $29.700 .000,00$ & $7.482 .805,56$ \\
\hline 57 & $18.887 .138,89$ & 1.755 & 22000 & $38.610 .000,00$ & $19.722 .861,11$ \\
\hline 59 & $27.642 .583,33$ & 2.500 & 21800 & $54.500 .000,00$ & $26.857 .416,67$ \\
\hline 60 & $12.386 .833,33$ & 890 & 22000 & $19.580 .000,00$ & 7.193.166,67 \\
\hline 61 & $22.168 .166,67$ & 1.455 & 22000 & $32.010 .000,00$ & $9.841 .833,33$ \\
\hline 62 & $26.146 .805,56$ & 1.354 & 22000 & $29.788 .000,00$ & $3.641 .194,44$ \\
\hline 63 & $26.349 .738,89$ & 1.355 & 22000 & $29.810 .000,00$ & $3.460 .261,11$ \\
\hline 64 & $16.749 .266,67$ & 1.100 & 22000 & $24.200 .000,00$ & $7.450 .733,33$ \\
\hline 65 & $19.709 .433,33$ & 1.650 & 22000 & $36.300 .000,00$ & $16.590 .566,67$ \\
\hline 66 & $10.948 .281,75$ & 1.145 & 22000 & $25.190 .000,00$ & $14.241 .718,25$ \\
\hline 67 & $21.393 .833,33$ & 1.560 & 22000 & $34.320 .000,00$ & $12.926 .166,67$ \\
\hline 68 & $21.031 .144,44$ & 1.750 & 22000 & $38.500 .000,00$ & $17.468 .855,56$ \\
\hline 69 & $25.234 .650,00$ & 2.000 & 21600 & $43.200 .000,00$ & $17.965 .350,00$ \\
\hline 70 & $13.090 .961,11$ & 1.100 & 22000 & $24.200 .000,00$ & $11.109 .038,89$ \\
\hline 71 & $20.049 .166,67$ & 1.340 & 22000 & $29.480 .000,00$ & $9.430 .833,33$ \\
\hline 72 & $12.827 .766,67$ & 900 & 22000 & $19.800 .000,00$ & $6.972 .233,33$ \\
\hline 73 & $9.152 .611,11$ & 870 & 22500 & $19.575 .000,00$ & $10.422 .388,89$ \\
\hline 74 & $11.119 .319,44$ & 900 & 22000 & $19.800 .000,00$ & $8.680 .680,56$ \\
\hline 75 & $34.159 .944,44$ & 2.900 & 21700 & $62.930 .000,00$ & $28.770 .055,56$ \\
\hline 76 & $25.677 .788,89$ & 2.500 & 21500 & $53.750 .000,00$ & 28.072.211,11 \\
\hline 77 & $24.215 .850,00$ & 2.650 & 21800 & $57.770 .000,00$ & $33.554 .150,00$ \\
\hline 78 & 19.462.361,11 & 1.900 & 21450 & $40.755 .000,00$ & $21.292 .638,89$ \\
\hline 79 & $23.535 .000,00$ & 2.900 & 21300 & $61.770 .000,00$ & $38.235 .000,00$ \\
\hline 80 & $34.062 .500,00$ & 3.250 & 21400 & $69.550 .000,00$ & $35.487 .500,00$ \\
\hline
\end{tabular}




\section{Uji Beda}

Group Statistics

\begin{tabular}{llr|r|r|r}
\hline & Akses Lembaga & N & Mean & \multicolumn{1}{c}{$\begin{array}{c}\text { Std. } \\
\text { Deviation }\end{array}$} & \multicolumn{2}{c}{ Std. Error Mean } \\
\hline Pendapatan Usahatani & Formal & 20 & 238.0500 & 75.37239 & 16.85378 \\
\cline { 2 - 6 } & Informal & 80 & 200.3000 & 65.06344 & 7.27431 \\
\hline
\end{tabular}

Independent Samples Test

\begin{tabular}{|c|c|c|c|c|c|c|c|c|c|c|}
\hline & & \multicolumn{2}{|c|}{$\begin{array}{c}\text { Levene's } \\
\text { Test for } \\
\text { Equality of } \\
\text { Variances }\end{array}$} & \multicolumn{7}{|c|}{ t-test for Equality of Means } \\
\hline & & \multirow[b]{2}{*}{$\mathbf{F}$} & \multirow[b]{2}{*}{ Sig. } & \multirow[b]{2}{*}{$\mathbf{t}$} & \multirow[b]{2}{*}{ df } & \multirow{2}{*}{$\begin{array}{l}\text { Sig. (2- } \\
\text { tailed) }\end{array}$} & \multirow{2}{*}{$\begin{array}{c}\text { Mean } \\
\text { Difference }\end{array}$} & \multirow{2}{*}{$\begin{array}{l}\text { Std. Error } \\
\text { Difference }\end{array}$} & \multicolumn{2}{|c|}{$\begin{array}{l}95 \% \text { Confidence } \\
\text { Interval of the } \\
\text { Difference }\end{array}$} \\
\hline & & & & & & & & & Lower & Upper \\
\hline \multirow[t]{2}{*}{$\begin{array}{l}\text { Pendapatan } \\
\text { Usahatani }\end{array}$} & $\begin{array}{l}\text { Equal } \\
\text { variances } \\
\text { assumed }\end{array}$ & .004 & .953 & 2.247 & 98 & .027 & 37.75000 & 16.79646 & 4.41797 & 71.08203 \\
\hline & $\begin{array}{l}\text { Equal } \\
\text { variances } \\
\text { not } \\
\text { assumed }\end{array}$ & & & 2.056 & 26.517 & .050 & 37.75000 & 18.35662 & .05320 & 75.44680 \\
\hline
\end{tabular}

